\title{
A TEXTURAL AND CHEMICAL STUDY OF WHITE MICA IN THE SOUTH MOUNTAIN BATHOLITH, NOVA SCOTIA: PRIMARY VERSUS SECONDARY ORIGIN
}

\author{
L.J. Ham and D.J. Kontak \\ Nova Scotia Department of Mines and Energy \\ P.O. Box 1087, Hallfax, Nova Scotia B3J $2 \times 1$ \\ Date Recelved October 23, 1987 \\ Date Accepted Apr11 14, 1988
}

\begin{abstract}
White mica (WM) in peraluminous granitold rocks of the South Mounta1n Batholith (SMB) and East Kemptville leucogranite (EKL) of Nova Scotia have been examined to see if parameters can be used to distinguish between primary and secondary grains. Texturally very little of the WM in the SMB can unequivocally be classified as primary. whereas most of the WM in the EKL is consistent with such an origin. Although discriminant diagrams which utilize major element chemistry do not provide unambiguous divisions between primary and secondary WM, there appear to be some chemical trends which indicate that the bulk composition of the host rock is an 1mportant control. This 1s best exemplified by volatile (1.e., F) and trace element contents, including the rare earth elements. For example, F, L1, Rb and Cs are systematically higher in WM from relatively more evolved units of the SMB. The importance of bulk rock composition is also indicated by the enrichment of lithophile elements in WM from the EKL, itself enriched in these same elements.

The octahedral impurities in WM of the SMB are accommodated via blotitic and phengitic substitutions, whereas WM from the EKL is dominantly pheng1tic. Comparison to experimentally determined stability ffelds for muscovite indicate that WM from the SMB re-equilibrated to $500-600^{\circ} \mathrm{C}$ in the more primitive units and $400-550^{\circ} \mathrm{C}$ in the more evolved units and greisens. Recent experimental data also suggest crystallization of the WM may have occurred at pressures of ca. $2 \mathrm{~kb}$ in melts with $2-3$ wt.\% $\mathrm{H}_{2} \mathrm{O}$.
\end{abstract}

On a examine les micas blancs (MB) dans les roches granitoïdes peralunineuses du Batholite de South Mountain (BSM) et du leucogranite d'Bast Kemptville (LEK) en Nouvelle-Ecosse afin de determiner si certains paramétres peuvent servir à distinguer les grains primaires des grains secondalres. A l'egard de la texture, une très faible proportion des MB dans le BSM peuvent, sans l'ombre d'un doute, être classés comme primaires alors que la plupart des MB dans le LEK sont compatibles avec une telle origine. Bien que les diagrames discriminant par chimie des ellements majeurs ne procurent aucune 11mite précise entre les MB primaires et secondalres, on semble y discerner des tendances chimiques indiquant une influence prepondèrante de la composition totale de 1 'encaissant. Les contenus en élements volatiles (1.e., F) et en traces, $\mathrm{y}$ comprises les terres rares, en sont la mellleure 1llustration. Par exemple, la teneur en F, $\mathrm{L1}, \mathrm{Rb}$ et $\mathrm{Cs}$ est systèmatiquement plus élevée dans les MB provenant des unités plus évoluées; par comparaison, du BSM. L'importance de la composition totale de la roche est aussi attestée par l'enrichissement en élements 11thophiles des MB du LEK (1u1-meme enrich1 en ces élêments).

L'accommodation des impurités octaédriques dans les MB du BSM se falt par le biais de substitutions biotitiques et phengitiques alors que les MB du LEK sont surtout phengitiques. Une comparaison des MB du BSM aux domaines de stabilités de la muscovite déterminés experimentalement révèle que leur ré-equilibrage s'est effectué entre 500 et $600^{\circ} \mathrm{C}$ dans les unités les plus primitives et entre 400 et $550^{\circ} \mathrm{C}$ dans les unités plus évoluées et les greisens. A la lumière de données expérimentales récentes, la cristallisation des MB aurait eu lieu à des pressions d'environ 2 kb dans des bains ayant de 2 à $3 \%$ en poids $\mathrm{d}^{\prime} \mathrm{H}_{2} \mathrm{O}$.

[Traduit par le journal]

\section{INTRODUCTION}

The occurrence of muscovite, or white mica (herein WM), in felsic igneous rocks is generally interpreted to reflect peraluminous bulk compositions (e.g., Clarke, 1981; Speer, 1984) and to indicate minimum pressures (1.e., depths) of crystallization. Although the former interpretation is often supported by the presence of add1tional peraluminous mineral phases, the latter is often highly controversial because of conflicting estimates derived using independent field evidence versus inferred pressures based on experimental data (e.g., Miller et al., 1981; Anderson and Rowley, 1981). In addition, attempts have been made to chemically characterize primary versus secondary. WM in granitic suites (Miller et al., 1981), but few applications of these results have been made to granitoid suites to see if the results are useful or valid. However, the recently published experimental data of Monier and Robert (1986) for muscovite solld solution chemistry provides a basis for interpreting WM chemistry in terms of absolute temperature and, therefore, potentially time of formation (1.e., primary or secondary).

We have selected the South Mountain Batholith (SMB), Nova Scotia (Fig. 1), to evaluate the relationship between texture, mode of occurrence, and chemistry of WM with respect to its host rock. Different textural varieties of WM are documented and then their major and volatile element chemistry is discussed in relationship to textural variety. A suite of WM mineral separates from granites and greisens of the SMB were also prepared and their major, trace (including rare earth element) and volatile element chemistry determined to monitor the changes that occurred during igneous fractionation and subsequent hydrothermal activity. In order to further document the control of bulk rock composition on the chemistry of WM, a suite of samples from the volatile-(1.e., F) and 11thophile-element enriched East Kemptville leucogranite (Kontak, 1987) was also analyzed for major, trace and volatile elements. 


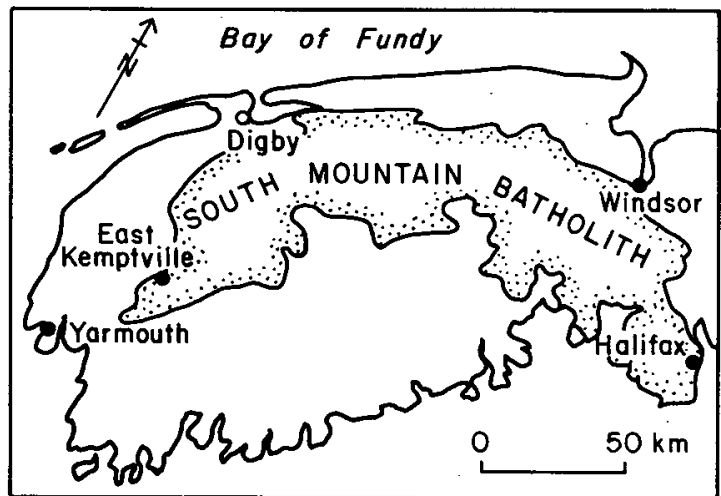

F1g. 1. Generalized map of southern Nova Scot1a showing the location of the South Mountain Batholith and East Kemptville leucogranite.

\section{GEOLOGY OF THE SOUTH MOUNTAIN BATHOLITH AND EAST KEMPTVILLE LEUCOGRANITE}

The SMB is a Late Devonian-Early Carboniferous, post tectonic, peraluminous composite batholith composed of granodiorite, monzogranite, and leucomonzogranite. The units show progressive mineralogical and chemical changes which reflect the evolution of the batholith from relatively mafic to more felsic sultes. During differentiation, there is a gradual increase in the modal percentage of muscovite and other peraluminous phases at the expense of biotite. In the most evolved rocks, blotite is absent and muscovite is generally the most abundant peraluminous mineral (t garnet, andalusite, cordierite). Where greisens and pegmatites are developed, WM is extensively developed. A complete review of the petrology of the SMB is given by Clarke and Muecke (1985 and references therein), and part of the eastern SMB is discussed in this 1ssue by MacDonald and Horne.

The East Kemptville leucogranite (EKI) is an informal name given by Kontak (1987) to the distinctive muscovite-topaz monzogranite which hosts the East Kemptville Sn-base metal deposit (F1g. 1). The EKL is characterized by its medium grained, equigranular texture and the presence of muscovite and topaz of presumed magmatic origin. The EKL contrasts with the rocks of the SMB by the conspicuous absence of biotite and enrichment in 11thophile elements, particularly F, L1, Rb, Cs, Sn and $\mathrm{Nb}$ (Kontak, 1987).

\section{METHODOLOGY AND ANALYTICAL PROCEDURES}

Over 150 pollshed thin sections were examined from samples representing a wide variety of localities and all rock units in the eastern half of the SMB. Five rock types are represented, viz., granodiorite, muscovite-biotite monzogranite, medium - to coarse-gralned blotite-muscovite leucomonzogranite, fine-to medium-gralned leucomonzogranite and leucomonzogranite porphyry. Based on detalled petrographic studies, 17 sections were selected for analysis ( 110 analyses in total) of the WM phases. For the EKL, a similar number of samples have been studied and 6 were selected for analysis of WM. In addition, muscovite separates from a suite of samples representative of a complete spectrum of rock types were prepared using conventional mineral separation techniques. Included in this sampling were 12 granites and 5 greisens from the SMB, and 2 granites and 4 greisens from the EKL.

A11 samples were analyzed for major and volatile ( $F$ and $C 1$ ) element contents using the JEOL 733 Superprobe at Dalhousie University, Halifax. A combined wavelength and energy dispersive analytical technique was employed with the following operating conditions: accelerating voltage $15 \mathrm{kV}$; current $5 \times 10^{-9} \mathrm{~A}$; beam diameter 1 um; counting time 40 seconds.

Trace elements were analyzed at Memorial University, St. John's, Newfoundland, using the ICP-MS technique as summarized by Strong and Longerich (1985). Ferrous iron was determined using a wet chemical digestion and titration technique at Technical University of Nova Scotia facilities, Hallfax.

\section{TEXTURAL CLASSIFICATION OF WHITE MICAS}

Several textural classifications have been proposed to distinguish between primary and secondary WM; most notable are those of Miller et al. (1981) and Saavedra (1978). The elght modes of occurrence of WM recognized in the SMB are summarized in Table 1 and compared to the criterla of the aforementioned authors. Additional occurrences not shown in Table 1 include pegmatitic, greisens and secondary after garnet. As is obvious from the petrographlc observations, WM of unambiguous primary origin is not common in the SMB based solely on textural criteria. In particular, we note that many of the isolated grains of ascribed secondary origin may have originally been primary, but because of their somewhat ambiguous texture are relegated to secondary status. Typical occurrences of the different categories of WM in the SMB are 11lustrated in Figure 2.

Muscovite from the EKL is considered primary based on the first criterla outlined for the SMB in Table 1. That 1s, the WM 1s of euhedral to subhedral habit, Inclusion free, and is of similar grain size to other magmatic phases. As in the SMB, extensive greisenization also occurs with development of secondary WM of distinctly different habit.

\section{CHEMISTRY OF WHITE MICAS}

Average chemical compositions for $W M$ from the SMB representing the different textural types referred to in Table 1 are given in Table 2 and analytical data for the 17 muscovite separates from SMB are given in Table 3 . Representative analyses for WM from the EKL are given in Table 4, and trace element data from 6 muscovite separates from EKL are in Table 5.

\section{Major and Volat1le Element Chemistry}

Observations based on the chemistry of the various textural varieties of WM are summarized as follows:

(1) Ti shows no consistent pattern which can be related to either its paragenesis (1.e., primary or secondary) or the phase it replaces. 
Table 1. Textural criteria used by various authors to recognize different types of muscovite

\begin{tabular}{|c|c|c|c|}
\hline $\begin{array}{l}\text { Study and } \\
\text { Location }\end{array}$ & $\begin{array}{l}\text { Mode of } \\
\text { Occurrence }\end{array}$ & Characteristics & Rock Type \\
\hline $\begin{array}{l}\text { Miller et al. } \\
\text { (1981) } \\
\text { North America } \\
\text { and Europe }\end{array}$ & $\begin{array}{l}\text { Igneous } \\
\text { (Primary) }\end{array}$ & $\begin{array}{l}\text { - grain size in comparison with the other obviously magmatic minerals } \\
\text { - subhedral to euhedral grain shape, with sharp terminations } \\
\text { - absence of inclusions of accessory minerals, particularly those from which } \\
\text { it could have been derived } \\
\text {-host rock relatively unaltered, clean and having igneous textures }\end{array}$ & $\begin{array}{l}16 \text { different peraluminous } \\
\text { granitoid plutons }\end{array}$ \\
\hline $\begin{array}{l}\text { Saavedra } \\
\text { (1978) } \\
\text { Central Spain }\end{array}$ & $\begin{array}{l}\text { Igneous } \\
\text { (Primary) }\end{array}$ & $\begin{array}{l}\text {-different twinning from biotite when intergrown and contact between two } \\
\text { micas well differentiated } \\
\text { - euhedral grains; may be well developed within plagioclase } \\
\text {-grain ideally free from inclusions and also not enclosed within minerals } \\
\text { which it could have been derived through alteration processes }\end{array}$ & peraluminous granites \\
\hline \multirow[t]{7}{*}{$\begin{array}{l}\text { This study } \\
\text { South Mountain } \\
\text { Batholith }\end{array}$} & $\begin{array}{l}\text { Igneous } \\
\text { (Primary) }\end{array}$ & $\begin{array}{l}\text { - euhedral to subhedral shape; inclusion-free grains } \\
\text { - sharply terminated grains, comparable in size to other magmatic minerals. } \\
\text { (generally coarse-grained) }\end{array}$ & $\begin{array}{l}\text { mainly leucomonzogranites; rarely } \\
\text { in more mafic and biotite-rich } \\
\text { rocks (granodiorite monzogranite) }\end{array}$ \\
\hline & $\begin{array}{l}\text { Igneous, inter- } \\
\text { grown with biotite } \\
\text { (Primary) }\end{array}$ & $\begin{array}{l}\text { - different twinning and cleavage planes between the micas } \\
\text {-euhedral contacts of muscovite against magmatic-looking biotite } \\
\text {-WM growing at oblique angles to biotite }\end{array}$ & leucomonzogranites \\
\hline & Secondary & $\begin{array}{l}\text { - individual grains that do not ' } f \text { it' the primary criteria } \\
\text { - subhedral to euhedral shape; same size as other magmatic minerals } \\
\text {-both enclosed within other minerals from which it could have formed and } \\
\text { within the groundmass }\end{array}$ & $\begin{array}{l}\text { all rock units: more plentiful } \\
\text { in leucomonzogranites }\end{array}$ \\
\hline & $\begin{array}{l}\text { Alteration } \\
\text { of biotite } \\
\text { (Secondary) }\end{array}$ & $\begin{array}{l}\text {-fine-grained, anhedral to subhedral shape; enclosing or enclosed within } \\
\text { biotite; mantling biotite and at edges of grains } \\
\text { - WM cleavage traces parallel those of biotite grains; the two micas have } \\
\text { similar twinning and show a diffuse contact between them }\end{array}$ & all rock units \\
\hline & $\begin{array}{l}\text { Alteration of } \\
\text { plagioclase and } \\
\text { K-feldspar } \\
\text { (Secondary) } \\
\end{array}$ & $\begin{array}{l}\text { - commonly occurs in many stages of alteration of plagioclase and } \mathrm{K} \text {-feldspar } \\
\text {-occurs as subhedral masses and well-developed grains } \\
\text {-initially forms along cleavage traces, fractures and in calcic-rich cores of } \\
\text { plagioclase }\end{array}$ & all rock units \\
\hline & $\begin{array}{l}\text { Alteration of } \\
\text { cordierite } \\
\text { (Secondary) }\end{array}$ & $\begin{array}{l}\text { - cordierite alters readily to pinite } \\
\text {-partial alteration occurring along edges; cleavage traces and twin planes } \\
\text {-advanced stages of alteration produce complete replacement of cordierite }\end{array}$ & $\begin{array}{l}\text { common in cordierite-bearing } \\
\text { leucomonzogranite; rarely in } \\
\text { in more mafic rocks }\end{array}$ \\
\hline & $\begin{array}{l}\text { Alteration of } \\
\text { andalusite } \\
\text { (Secondary) }\end{array}$ & $\begin{array}{l}\text { - andalusite alters readily to sericite and WM } \\
\text {-restricted development along grain margins to extensive alteration involving } \\
\text { almost complete replacement of aluminosilicate }\end{array}$ & $\begin{array}{l}\text { late-stage pegmatites, monzo- } \\
\text { granites, leucomonzogranites, } \\
\text { leucogranite and aplites }\end{array}$ \\
\hline
\end{tabular}



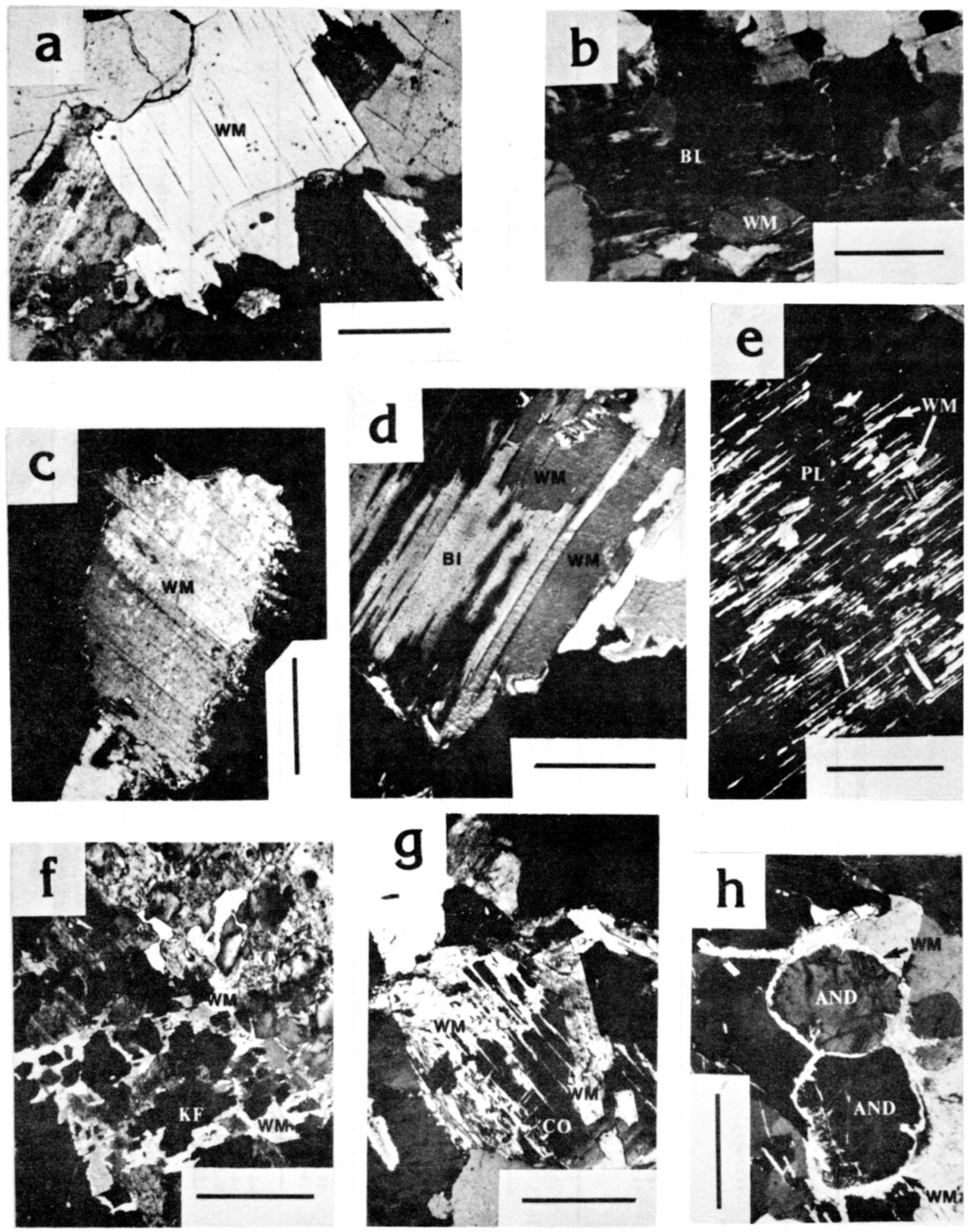

F1g. 2. Photomicrographs of white mica in granitoid rocks of the South Mounta1n Batholith (bar scale in all figures is $0.5 \mathrm{~mm}$ length): (a) primary WM in leucomonzogranite showing subhedral morphology, equant shape and sharp crystal boundaries (cf. F1g. 2c); (b) primary WM intergrown with blotite in a biotite monzogranite; (c) large grain of secondary WM showing anhedral morphology and ragged crystal outlines; (d) WM replacing earlier magmatic biot1te; (e) WM replacing plagioclase grain along cleavage traces; (f) WM replacing alkall feldspar; (g) WM replacing cordierite grain; (h) WM replacing subhedral andalusite grains in a fine grained, equigranular leucogranite. 
Table 2. Average chemical compositions for different textural types of WM from the SMB

\begin{tabular}{|c|c|c|c|c|c|c|c|}
\hline & 1 & 2 & 3 & 4 & 5 & 6 & 7 \\
\hline $\mathrm{SiO}_{2}$ & $45.67 \pm 0.70$ & $45.44 \pm 0.64$ & $45.48 \pm 0.40$ & $45.06 \pm 0.51$ & $45.50 \pm 0.28$ & $44.69 \pm 0.29$ & $45.96 \pm 0.85$ \\
\hline $\mathrm{TiO}_{2}$ & $0.07 \pm 0.07$ & $0.38 \pm 0.11$ & $0.14 \pm 0.09$ & $0.21 \pm 0.09$ & $0.08 \pm 0.07$ & $0.26 \pm 0.05$ & $0.30 \pm 0.14$ \\
\hline $\mathrm{Al}_{2} \mathrm{O}_{3}$ & $35.57 \pm 0.36$ & $35.86 \pm 0.66$ & $35.14 \pm 0.71$ & $34.27 \pm 1.28$ & $35.37 \pm 0.48$ & $34.36 \pm 0.62$ & $34.15 \pm 1.49$ \\
\hline $\mathrm{FeO}$ & $2.08 \pm 0.55$ & $1.34 \pm 0.19$ & $1.78 \pm 0.46$ & $2.43 \pm 0.69$ & $2.26 \pm 0.44$ & $1.82 \pm 0.35$ & $1.83 \pm 0.48$ \\
\hline $\mathrm{NiO}$ & $0.15 \pm 0.12$ & $0.17 \pm 0.12$ & $0.13 \pm 0.12$ & $0.00 \pm 0.00$ & $0.00 \pm 0.00$ & $0.00 \pm 0.00$ & $0.03 \pm 0.08$ \\
\hline MnO & $0.07 \pm 0.02$ & $0.01 \pm 0.01$ & $0.05 \pm 0.04$ & $0.03 \pm 0.05$ & $0.09 \pm 0.04$ & $0.01 \pm 0.01$ & $0.06 \pm 0.03$ \\
\hline $\mathrm{MgO}$ & $0.70 \pm 0.06$ & $0.54 \pm 0.07$ & $0.67 \pm 0.07$ & $0.83+0.19$ & $0.70+0.18$ & $0.69 \pm 0.16$ & $1.17 \pm 0.44$ \\
\hline $\mathrm{CaO}$ & $0.01 \pm 0.00$ & $0.01 \pm 0.01$ & $0.01 \pm 0.01$ & $0.00 \pm 0.00$ & $0.01 \pm 0.01$ & $0.03 \pm 0.01$ & $0.01 \pm 0.01$ \\
\hline $\mathrm{Na}_{2} \mathrm{O}$ & $0.81 \pm 0.11$ & $0.56 \pm 0.07$ & $0.72 \pm 0.15$ & $0.70 \pm 0.16$ & $0.74 \pm 0.10$ & $0.67 \pm 0.04$ & $0.37 \pm 0.10$ \\
\hline $\mathrm{K}_{2} \mathrm{O}$ & $10.46 \pm 0.17$ & $10.65 \pm 0.38$ & $10.33 \pm 0.35$ & $10.66 \pm 0.33$ & $10.59 \pm 0.26$ & $11.11 \pm 0.23$ & $11.14 \pm 0.28$ \\
\hline \multirow[t]{2}{*}{$\mathrm{F}$} & $0.50 \pm 0.07$ & $0.41 \pm 0.14$ & $0.44 \pm 0.09$ & $0.86 \pm 0.30$ & $0.57 \pm 0.17$ & $0.62 \pm 0.23$ & $0.21 \pm 0.09$ \\
\hline & 8 & 9 & 10 & 11 & 12 & 13 & 14 \\
\hline $\mathrm{SiO}_{2}$ & $45.74 \pm 0.32$ & $45.28 \pm 0.26$ & $44.99 \pm 0.17$ & $44.76 \pm 0.64$ & $45.51 \pm 0.43$ & $46.22 \pm 0.82$ & $45.52 \pm 0.28$ \\
\hline $\mathrm{TiO}_{2}$ & $0.25 \pm 0.14$ & $0.16 \pm 0.20$ & $0.07 \pm 0.02$ & $0.10 \pm 0.13$ & $0.64 \pm 0.25$ & $0.63 \pm 0.47$ & $0.14 \pm 0.02$ \\
\hline $\mathrm{Al}_{2} \mathrm{O}_{3}$ & $34.66 \pm 2.15$ & $35.72 \pm 0.23$ & $36.11 \pm 0.39$ & $36.11 \pm 0.76$ & $36.07 \pm 0.25$ & $36.28 \pm 1.38$ & $35.49 \pm 0.51$ \\
\hline $\mathrm{FeO}$ & $1.91 \pm 0.87$ & $2.23 \pm 0.45$ & $2.26 \pm 0.08$ & $2.07 \pm 0.55$ & $1.00 \pm 0.05$ & $0.93 \pm 0.18$ & $1.42 \pm 0.16$ \\
\hline $\mathrm{NiO}$ & $0.13 \pm 0.12$ & $0.19 \pm 0.08$ & $0.13 \pm 0.10$ & $0.14 \pm 0.10$ & $0.25 \pm 0.00$ & $0.25 \pm 0.00$ & $0.00 \pm 0.00$ \\
\hline Mno & $0.02 \pm 0.03$ & $0.11 \pm 0.09$ & $0.08 \pm 0.04$ & $0.07 \pm 0.04$ & $0.03 \pm 0.02$ & $0.03+0.02$ & $0.05 \pm 0.01$ \\
\hline $\mathrm{MgO}$ & $1.15 \pm 0.58$ & $0.34 \pm 0.10$ & $0.18 \pm 0.03$ & $0.26 \pm 0.13$ & $0.49 \pm 0.03$ & $0.41 \pm 0.17$ & $0.75 \pm 0.12$ \\
\hline $\mathrm{CaO}$ & $0.01 \pm 0.02$ & $0.00 \pm 0.00$ & $0.01 \pm 0.01$ & $0.00 \pm 0.00$ & $0.00 \pm 0.00$ & $0.02 \pm 0.01$ & $0.03 \pm 0.03$ \\
\hline $\mathrm{Na}_{2} \mathrm{O}$ & $0.42 \pm 0.15$ & $0.85 \pm 0.15$ & $0.91 \pm 0.10$ & $1.22 \pm 1.34$ & $0.56 \pm 0.09$ & $0.47 \pm 0.14$ & $0.59 \pm 0.03$ \\
\hline $\mathrm{K}_{2} \mathrm{O}$ & $10.56 \pm 0.40$ & $9.98 \pm 0.18$ & $10.13 \pm 0.37$ & $10.63 \pm 0.31$ & $9.95 \pm 0.22$ & $10.15 \pm 0.46$ & $10.62 \pm 0.30$ \\
\hline$F^{2}$ & $0.30 \pm 0.08$ & $0.58 \pm 0.17$ & $0.72 \pm 0.17$ & $0.43 \pm 0.18$ & $0.27 \pm 0.03$ & $0.28 \pm 0.03$ & $0.33 \pm 0.04$ \\
\hline
\end{tabular}
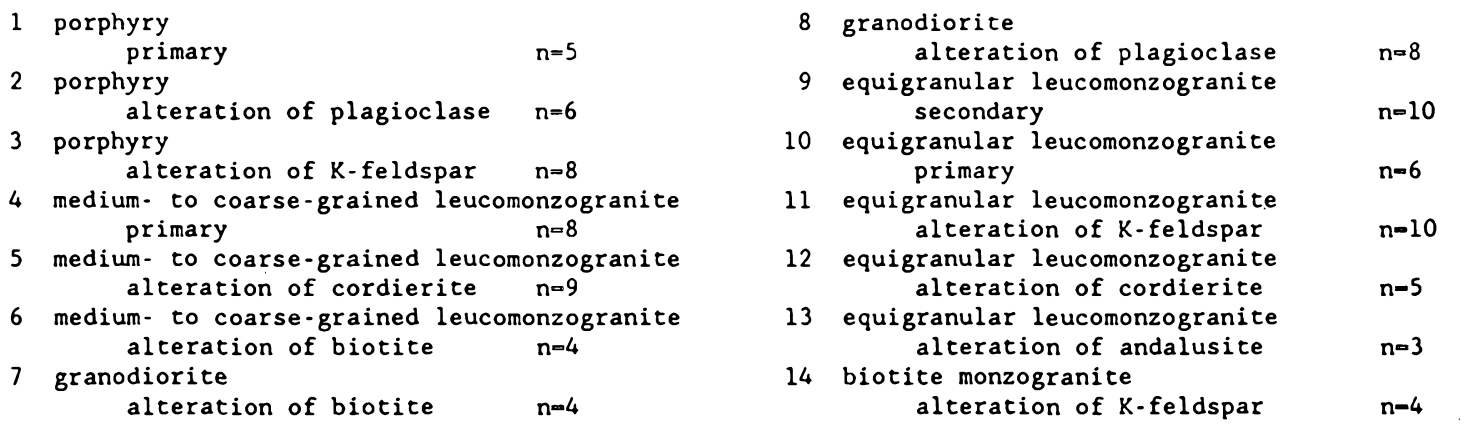

Table 3. Major and trace element chemistry of South Mountain Batholith white mica

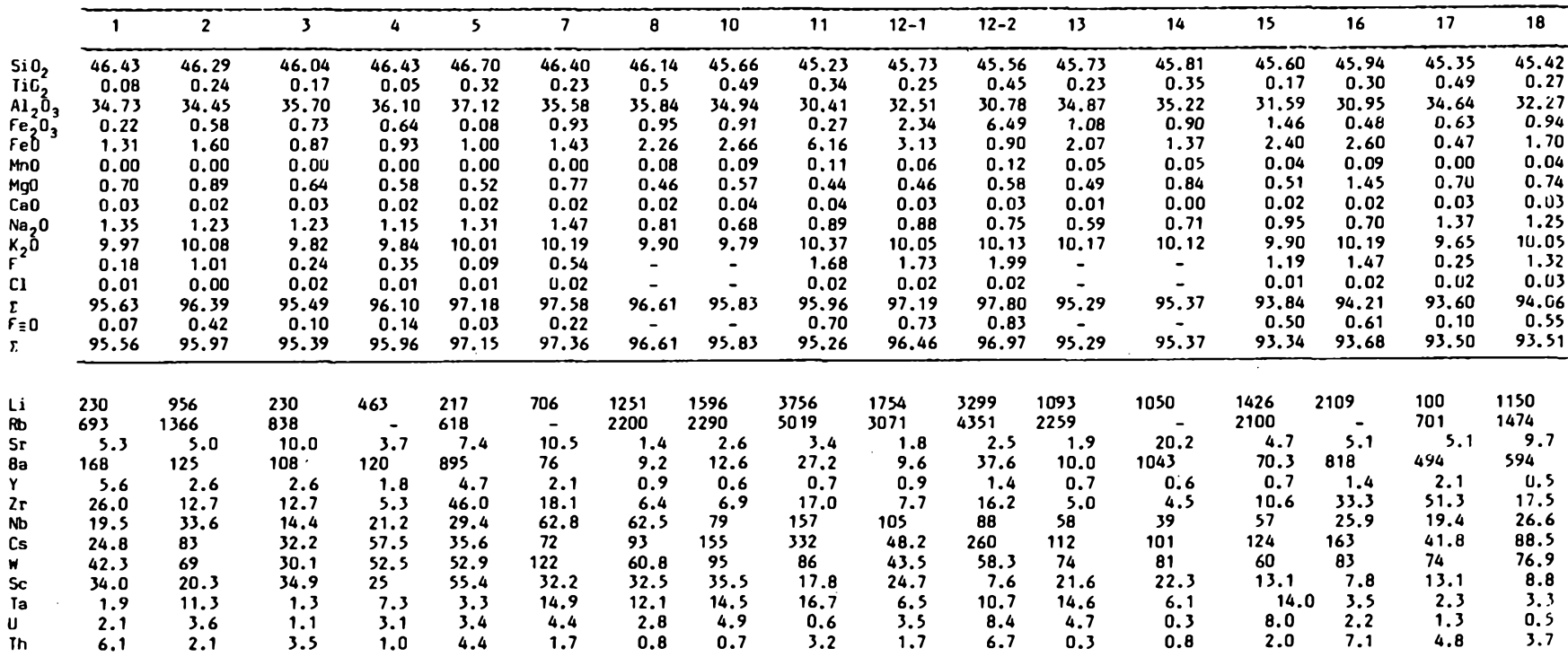

Samples correspond to the following groupings (as discussed in the text and in Figs. 6 and 7): group 1 - 1, 2, 3, 4; group 2 - 5, 7, 8; group $3-10,11,12-1,12-2,13$; group 4-14, 15, 16, $17,18$. 
Table 4. Representative chemical analyses of white mica, East Kemptville leucogranite

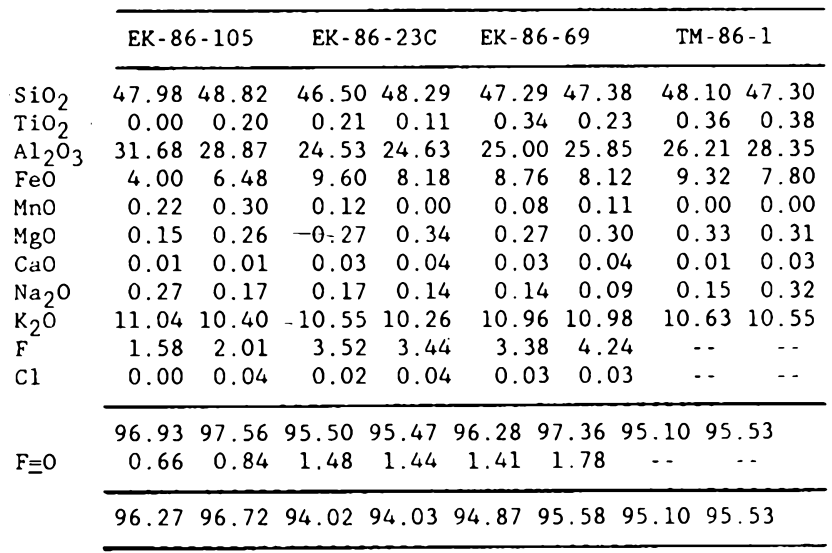

Table 5. Trace element chemistry of East Kemptville white micas

\begin{tabular}{lrrrrrr} 
& $13 \mathrm{~A}$ & $23 \mathrm{C}$ & 26 & 116 & 117 & 118 \\
\cline { 2 - 7 } $\mathrm{Li}$ & 5543 & 7386 & 940 & 2689 & 2801 & 2795 \\
$\mathrm{Rb}$ & 5499 & 6142 & 2491 & 4467 & 4400 & 4275 \\
$\mathrm{Sr}$ & 35.0 & 50.1 & 65.8 & 4.1 & 4.8 & 4.1 \\
$\mathrm{Ba}$ & 38.5 & 7.3 & 172 & 62.1 & 55.1 & 40.5 \\
$\mathrm{Y}$ & 2.2 & 7.9 & 2.0 & 0.9 & 0.5 & 0.2 \\
$\mathrm{Zr}$ & 32.3 & 37.2 & 27.1 & 15.2 & 11.2 & 10.8 \\
$\mathrm{Nb}$ & 129 & 153 & 42.7 & 93.9 & 34.1 & 25.5 \\
$\mathrm{Cs}$ & 388 & 354 & 74.9 & 237 & 227 & 191 \\
$\mathrm{~W}$ & 83.7 & 82.3 & 58.0 & 72 & 38.4 & 51.9 \\
$\mathrm{Sc}$ & 16.1 & 10.0 & 3.0 & 1.5 & 2.0 & 1.1 \\
$\mathrm{Ta}$ & 31.9 & 45.3 & 8.5 & 7.1 & 8.2 & 4.6 \\
$\mathrm{U}$ & 9.5 & 36.9 & 29.8 & 9.4 & 8.9 & 7.8 \\
$\mathrm{Th}$ & 8.2 & 9.1 & 4.1 & 2.4 & 1.7 & 1.5 \\
\hline
\end{tabular}

Samples are from granites (13A, 23C), green sericitic greisen (26) and white sericitic greisens $(116,117,118)$

(2) $\mathrm{Al}_{2} \mathrm{O}_{3}$ varies from about 34 to $36.5 \mathrm{wt} . \%$, but again ho systematic relationship to textural varlety is noted. However, granodiorite WM is systematically depleted in $\mathrm{Al}$, and $\mathrm{WM}$ replacing aluminous phases (e.g., cordierite, andalusite) is generally enriched in $\mathrm{A} 1$.

(3) $\mathrm{Na}_{2} \mathrm{O}$ is consistent1y $0.5-1.0$ wt.\%, with no preference for any particular variety of WM.

(4) $\mathrm{Mn}$ and $\mathrm{Ca}$ are systematically very low in all WM ( $<0.1$ wt.\%).

(5) $\mathrm{MgO}$ is systematically higher in WM from granodiorite $(\sim 1.15$ wt.\%) than other granites $(<0.2-0.8$ wt.\%).

(6) $F$ shows a general enrichment in WM from granodiorites to the more evolved units (F1g. 3), but there is no-apparent enrichment in primary versus secondary WM.

Comparison of the chemistry of the WM to the fields defined by Miller et al. (1981) for primary and secondary muscovite indicates no consistent correlation of any textural variety of WM analyzed in this study. However, the data do cluster near the musqovite end member in Monier and Robert's (1986) $\mathrm{M}^{2+}$-A1-S1 plot (Fig. 4, top left). In terms of the substitutions discussed by these authors, the SMB data indicate that both biotitic and

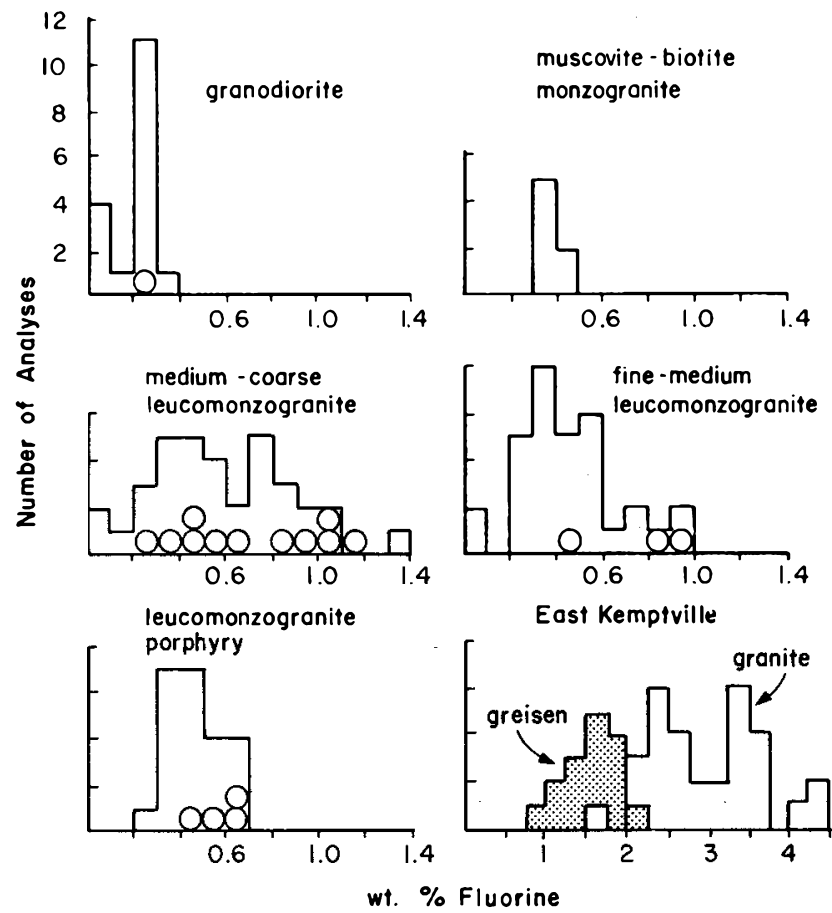

F1g. 3. Fluorine contents of muscovites from the South Mounta1n Batholith and East Kemptville leucogranite and assoclated greisens. The circles denote analyses of texturally primary muscovite.

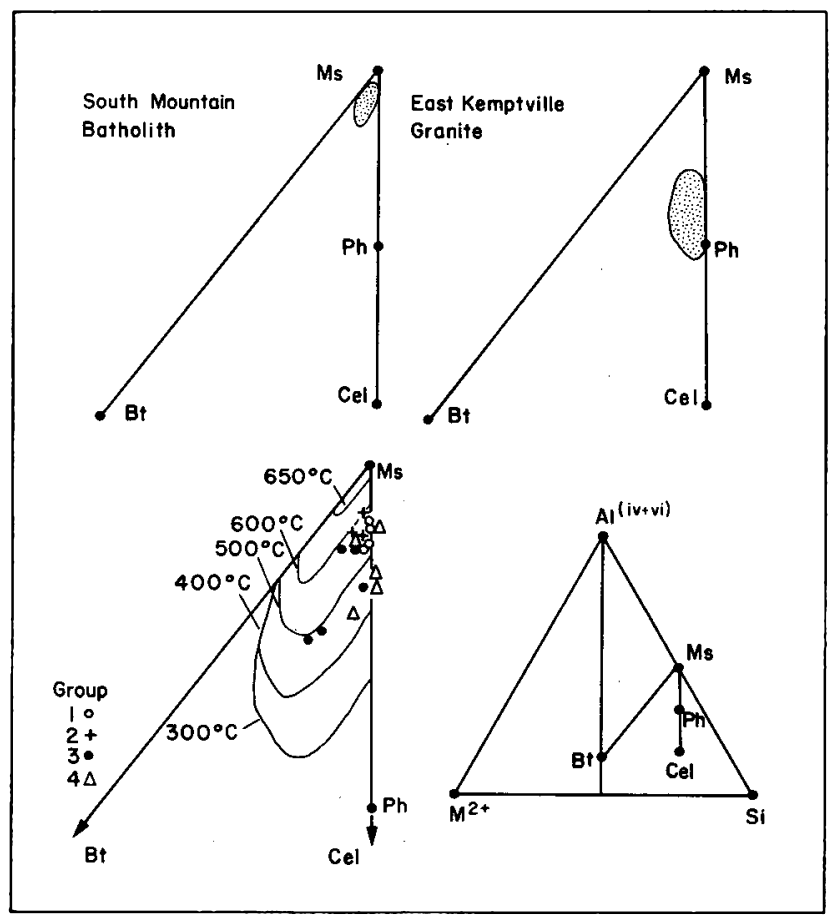

F1g. 4 . Muscovite compositions plotted in the ternary A1S1-M diagram of Monler and Robert (1986), showing the extent of biotitic and celadonitic substitutions at different temperatures. Abbrevlations are as follows: Bt-biotite, Ms-muscovite, $\mathrm{Ph}$-phengite, Cel-celadonite. Groups $1-4$ as specified in Table 3.

pheng1t1c subst1tutions are important. In addition, the data conform to their field for WM of inferred primary origin plotting between the 500- 
$650^{\circ} \mathrm{C}$ isotherms in this diagram (Fig. 4).

The composition of WM in the EKL contrasts markedly with that in the SMB by its relative enrichment in total $\mathrm{Fe}$ and $\mathrm{Si}$ (Fig. 5) and depletion of A1 (compare Tables 2 and 4). These chemical features are reflected in Figure 4', (top right) which shows that the WM from the EKL is phengitic in the plot of Monier and Robert (1986). Abundances of the other cations ( $\mathrm{Mg}, \mathrm{Ca}, \mathrm{Mn}, \mathrm{Ti}$, $\mathrm{Na}$ ) in the WM are low and comparable to values for WM of the SMB. However, the F contents for these WM are enriched compared to values for the SMB (i.e., 2-4 wt.\% versus 0.2-1.2 wt.\%; Fig. 3). Because of the extensive development of greisen in the EKL and potential for development of secondary WM, the composition of greisen WM is compared to that of WM of magmatic origin for $\mathrm{F}, \mathrm{Fe}$, and $\mathrm{Si}$ in Figures 3 and 5 . As the data indicate, there is'a distinct separation of the two types of WM with respect to these chemical parameters.

The major element chemistry of the WM separates (Table 3) are grouped according to their occurrence, viz., group $1=$ muscovite-biotite monzogranite, group $2=$ muscovite-biotite leucomonzogranite, group $3=$ muscovite \pm biotite leucogranite, and group $4=$ muscovite-rich greisens. The chemistry of the WM generally reflects the groupings in terms of granite evolution, with groups 1 and 2 relatively enriched in $\mathrm{Si}, \mathrm{Al}, \mathrm{Mg}$ and $\mathrm{Na}$, whereas group 3 has higher contents of $\mathrm{Fe}$ and $\mathrm{F}$. For group $4 \mathrm{WM}$, the trends are erratic, indicating that the protolith controls to a large extent the chemistry of secondary micas, a conclusion simflar to that reached by Strong and Chatterjee (1985) in their study of phyllosilicate chemistry. In terms of the ternary components $\mathrm{M}^{2 f}$ $\mathrm{Al}-\mathrm{Si}$, the WM mineral separates generally plot on the muscovite-celadonite join with some biotitic

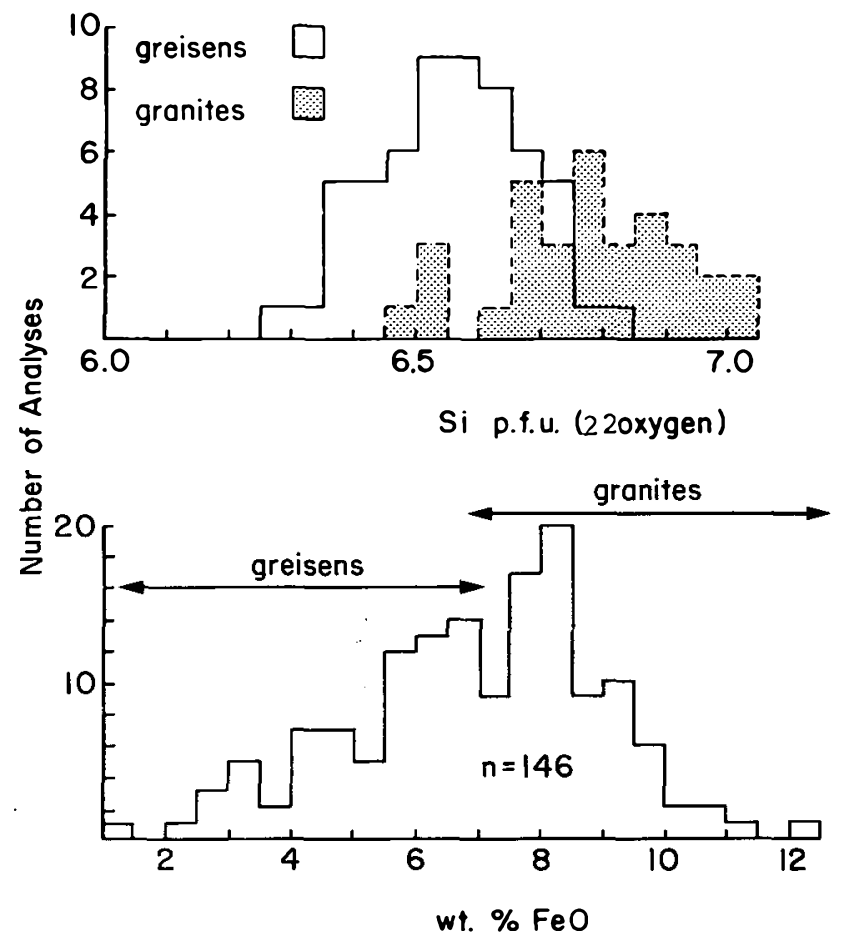

Fig. 5. Chemical data ( $\mathrm{S} 1$ and $\mathrm{Fe}$ ) for muscovite from the East Kemptville leucogranite and associated greisens. substitution (Fig. 4, lower left). However, WM of groups 3 and 4 show considerably more celadonitic substitution. These chemical features are consistent with the probable lower temperatures of formation (ca. $400-550^{\circ} \mathrm{C}$ ) for the latter $\mathrm{WM}$ as compared to groups 1 and 2 (ca. $500-600^{\circ} \mathrm{C}$ ).

\section{Trace Element Chemistry}

Trace element data for WM separates from the SMB (Table 3) show the following features:

(1) General enrichment from group 1 through to group 3 for $\mathrm{Li}, \mathrm{Rb}, \mathrm{Nb}, \mathrm{Cs}, \mathrm{W}, \mathrm{Ta}$ and depletion of $\mathrm{Sr}, \mathrm{Ba}, \mathrm{Y}, \mathrm{Sc}$. Some elements (i.e., $\mathrm{Zr}, \mathrm{Th}, \mathrm{U}$ ) show irregular patterns with respect to indices of differentiation.

(2) The greisen samples (group 4) are characterized by large varlations for particular elements, although certain trends are maintained as indicated (for example) in plots of $\mathrm{Li}$ versus $\mathrm{Cs}$ and $\mathrm{F}$ (Fig. 6).

(3) Greisen samples show a reverse differentiation trend in terms of $\mathrm{Ba}$ versus $\mathrm{Sr}$ (Fig. 6) compared to the other data.

(4) Covariation plots for all the data show excellent interelement trends as illustrated, for example, with $C s$ versus $L i$ and $\mathrm{Rb}$ (Fig. 6). A strong positive correlation is also noted for $F$ and Li (Fig. 6), but only to ca. $1.5 \mathrm{wt} . \% \mathrm{~F}$ and 2000 ppm Li; above these concentrations, Li increases at similar $\mathrm{F}$ contents.

Trace element data for WM from the EKL (Table 5) show greater enrichment of $\mathrm{Rb}, \mathrm{Li}, \mathrm{Nb}, \mathrm{Cs}, \mathrm{U}, \mathrm{Th}$, Ta compared to the SMB data. Surprisingly also is the higher concentration of $\mathrm{Sr}(35-50$ versus $<10$ $\mathrm{ppm}$ ) in these samples compared to WM from the SMB, a feature also shown by the whole rock data for the EKL (Kontak, 1987). Comparison of WM chemistry from greisen versus granite at East Kemptville (Table 5) demonstrates marked differences, with WM in granites being enriched in most of the analyzed elements.
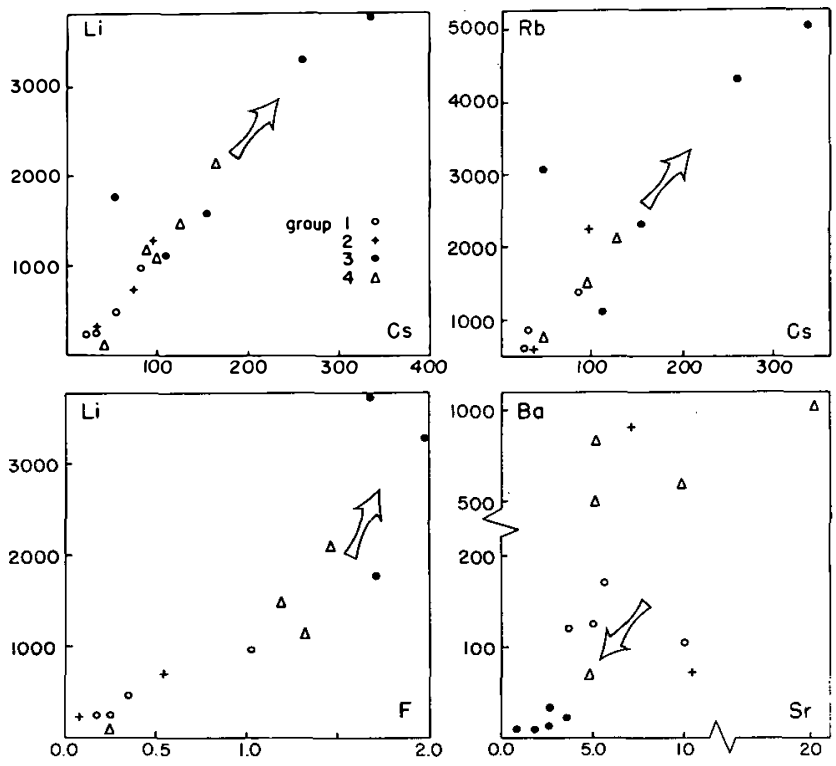

Fig. 6. Bivariant plots of trace element data for mineral separates from the South Mountain Batholith. The arrows indicate the inferred direction of differentiation. $F$ in wt.\% and trace elements in ppm. 


\section{Rare Earth Element Chemistry}

REE data for WM are given in Table 6 and chondrite-normalized patterns are shown in Figure 7. In general, WM from the SMB show broadly similar REE patterns with the LREE enriched over the HREE and negative Eu anomalies. Where there is an overall depletion of REE for WM within a group the pattern remains relatively constant (e.g.. group 1 in Fig. 7). However, aside from these generalities, there are important systematic trends observed for the REE data which deserve particular emphasis :

(1) The patterns are simflar to those of metaluminous to peraluminous igneous rocks in general (e.g., Hanson, 1980), although absolute REE contents are less. In fact, the trend of diminished fractionation (1.e.) ( $\mathrm{La} / \mathrm{Yb}$ ) approaching 1) with decreasing REE abundance, as illustrated well for group $2 \mathrm{WM}$, is identical to that observed for whole rock data within the SMB (e.g., Muecke and Clarke, 1981; Kontak et al., this volume).

(2) There is a general depletion of total REB from group 1 to $3(1-25 \pm 14,2-17 \pm 17,3-7 \pm 5)$, Eu values decrease, and patterns become less fractionated. However, the data for greisen WM does not continue this trend and, as observed with the other trace element data, there is a large variation in abundance and in fractionation.

REE data for WM from the EKL contrasts with that for the SMB data in the following ways: (1) they have less fractionated LREE profiles (1.e., $(\mathrm{La} / \mathrm{Sm})$ values are smaller), (2) they are overali less fractionated in terms of $(\mathrm{La} / \mathrm{Yb})$ except for the more evolved samples in group 2 and 3 (e.g.. samples $8,10,11,12-1)$. (3) the patterns have a distinct inflection at $\mathrm{Tb}$, and (4) they have much larger Eu*/Eu values (ca. $80-100$ versus $<10-20$ ), excluding some of the greisen samples. As with the

Table 6. Rare earth element analyses of white mica

\begin{tabular}{|c|c|c|c|c|c|c|c|c|c|c|}
\hline 1 & 2 & 3 & 4 & 5 & 6 & 7 & 8 & 13 & 14 & 15 \\
\hline 7.99 & 2.81 & 5.64 & 1.52 & 7.19 & 1.63 & 0.28 & 0.61 & 0.92 & 1.20 & 0.85 \\
\hline 20.94 & 6.76 & 14.97 & 3.69 & 17.18 & 4.24 & 0.81 & 1.64 & 1.20 & 2.36 & 2.32 \\
\hline 2.29 & 0.84 & 1.58 & 0.45 & 2.09 & 0.53 & 0.10 & 0.20 & 0.22 & 0.26 & 0.28 \\
\hline 8.35 & 3.14 & 5.94 & 1.75 & 7.92 & 1.95 & 0.35 & 0.76 & 0.89 & 0.98 & 1.08 \\
\hline 2.16 & 0.84 & 1.42 & 0.56 & 2.15 & 0.53 & 0.12 & 0.22 & 0.18 & 0.25 & 0.25 \\
\hline 0.079 & 0.045 & 0.113 & 0.039 & 0.111 & 0.033 & 0.009 & 0.014 & 0.027 & & 0.027 \\
\hline 1.76 & 0.77 & 1.08 & 0.51 & 1.93 & 0.42 & 0.11 & 0.15 & 0.14 & 0.45 & 0.24 \\
\hline 0.27 & 0.12 & 0.14 & 0.09 & 0.25 & 0.07 & 0.02 & 0.02 & 0.02 & 0.02 & 0.03 \\
\hline 1.37 & 0.62 & 0.67 & 0.46 & 1.13 & 0.39 & 0.15 & 0.14 & 0.11 & 0.14 & 0.19 \\
\hline 0.20 & 0.09 & 0.11 & 0.05 & 0.17 & 0.06 & 0.03 & 0.02 & 0.02 & 0.02 & 0.03 \\
\hline 0.47 & 0.22 & 0.24 & 0.11 & 0.40 & 0.20 & 0.09 & 0.06 & 0.06 & 0.09 & 0.08 \\
\hline 0.06 & 0.02 & 0.03 & 0.01 & 0.05 & 0.15 & 0.01 & 0.01 & 0.01 & 0.01 & 0.01 \\
\hline 0.41 & 0.15 & 0.20 & 0.09 & 0.30 & 0.27 & 0.10 & 0.07 & 0.07 & 0.06 & 0.08 \\
\hline 0.05 & 0.02 & 0.02 & 0.01 & 0.04 & 0.04 & 0.01 & 0.01 & 0.01 & 0.01 & 0.01 \\
\hline 46.39 & 16.44 & 32.15 & 9.33 & 40.91 & 10.51 & 2.18 & 4.18 & 3.87 & 5.85 & 5.47 \\
\hline 18 & $12-1$ & $12 \cdot 2$ & 11 & 17 & $13 \mathrm{~A}$ & $23 \mathrm{C}$ & 26 & 116 & 117 & 118 \\
\hline 2.47 & 0.50 & 2.84 & 0 & 4.46 & 1.77 & 2.40 & 0.87 & 5.95 & 0.35 & 0.57 \\
\hline 6.27 & 1.50 & 8.00 & 2.50 & 10.99 & 4.59 & 7.23 & 2.26 & 13.15 & 1.07 & 0.54 \\
\hline 0.75 & 0.19 & 1.03 & 0.31 & 1.33 & 0.57 & 0.93 & 0.28 & 1.41 & 0.13 & 0.06 \\
\hline 2.97 & 0.74 & 3.71 & 1.07 & 4.95 & 2.05 & 3.31 & 0.10 & 5.16 & 0.43 & 0.23 \\
\hline 0.66 & $\begin{array}{l}0.23 \\
0.010\end{array}$ & $\begin{array}{l}0.96 \\
0.000\end{array}$ & $\begin{array}{l}0.32 \\
0.000\end{array}$ & 1.07 & 0.79 & $\begin{array}{l}1.43 \\
0.010\end{array}$ & $\begin{array}{l}0.42 \\
0.140\end{array}$ & 0.95 & 0.17 & 0.09 \\
\hline 0.58 & $\begin{array}{l}0.010 \\
0.21\end{array}$ & $\begin{array}{l}0.000 \\
0.68\end{array}$ & $\begin{array}{l}0.000 \\
0.29\end{array}$ & $\ddot{0.58}$ & 0.54 & $\begin{array}{l}0.010 \\
1.48\end{array}$ & $\begin{array}{l}0.140 \\
0.34\end{array}$ & 0.79 & 0.17 & 0.08 \\
\hline 0.04 & 0.04 & 0.09 & 0.04 & 0.07 & 0.12 & 0.37 & 0.10 & 0.11 & 0.03 & 0.01 \\
\hline 0.15 & 0.22 & 0.39 & 0.21 & 0.42 & 0.57 & 1.96 & 0.55 & 0.64 & 0.15 & 0.07 \\
\hline 0.01 & 0.03 & 0.05 & 0.02 & 0.07 & 0.07 & 0.25 & 0.07 & 0.10 & 0.01 & 0.01 \\
\hline 0.05 & 0.08 & 0.10 & 0.06 & 0.24 & 0.14 & 0.50 & 0.13 & 0.34 & 0.04 & 0.02 \\
\hline 0.00 & 0.01 & 0.01 & 0.01 & 0.04 & 0.02 & 0.06 & 0.02 & 0.05 & 0.00 & 0.00 \\
\hline 0.04 & 0.08 & 0.09 & 0.07 & 0.24 & 0.13 & 0.39 & 0.12 & 0.40 & 0.03 & 0.02 \\
\hline 0.00 & 0.01 & 0.01 & 0.01 & 0.03 & 0.01 & 0.04 & 0.01 & 0.01 & 0.00 & 0.00 \\
\hline 99 & 3.85 & .96 & 5.86 & 24.49 & 11.37 & 20.36 & 6.27 & 29.06 & 2.58 & 1.70 \\
\hline
\end{tabular}

SMB data, the WM patterns mimic the REE plots for the EKL (Kontak, unpublished data).

REE data for the greisen WM at East Kemtpville (Fig. 7) show an overall depletion compared to that which characterizes the primary WM, although the patterns are very similar. The Tb inflection noted above is also present in the greisen WM, albeit more in some than others. Compared to the greisen WM in the SMB, those from East Kemptville are markedis depleted in the REE, particularly the LREE, and are less fractionated.

\section{DISCUSSION}

The data presented herein indicate that textural and chemical signatures of WM can be highly varlable even within a single composite intrusion
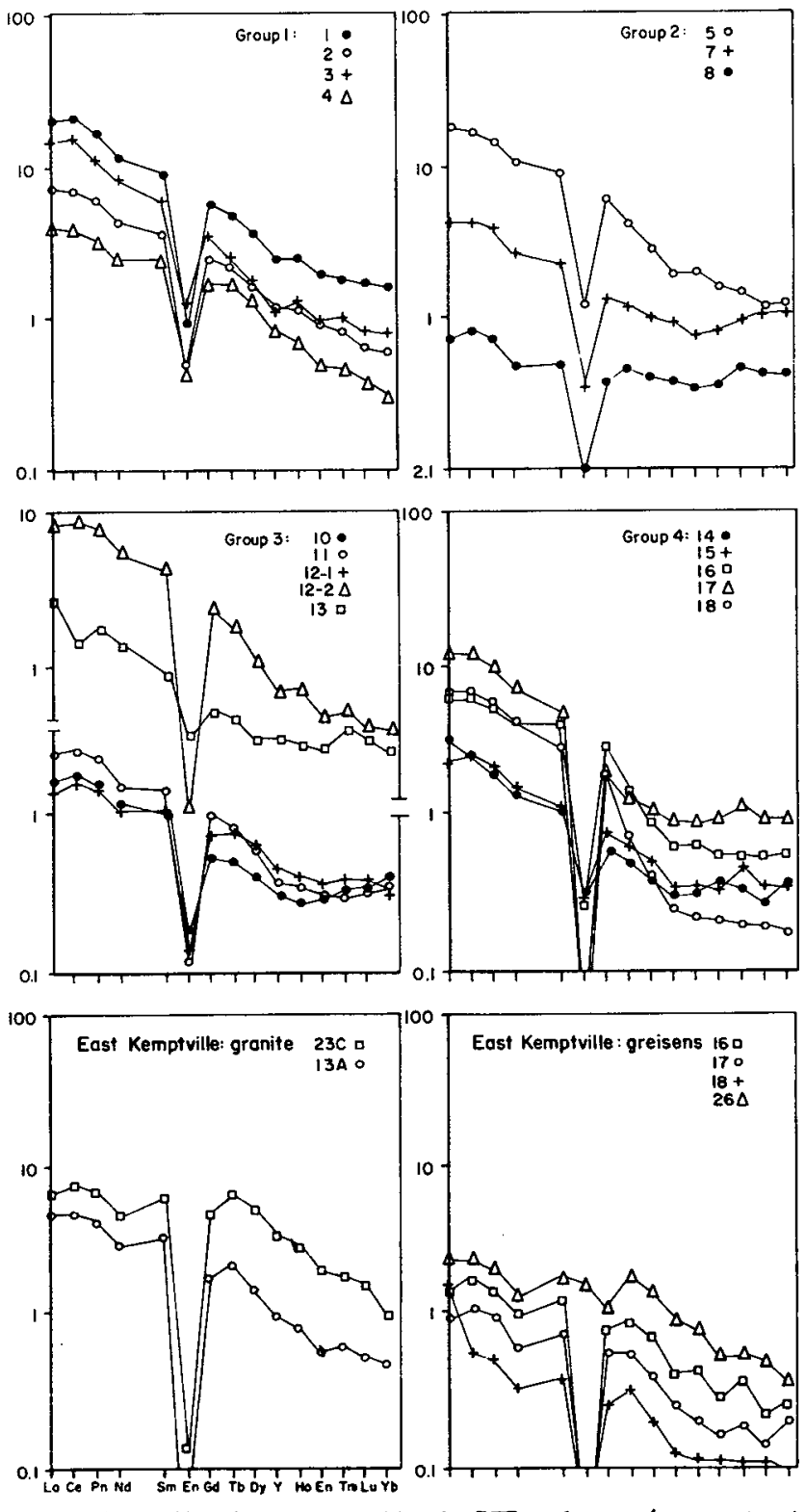

F18. 7. Chondrite-normalized REB plots (muscovite/ chondritic values) for muscovite separates from the South Mountain Batholith and Bast Kemptville leucogranite and associated greisens. 
(e.g. the SMB). The data also illustrate that a simple interpretation of WM history can rarely be unequivocal and, instead, several potential explanations may be required to account for the mineralogical features of WM within a single granitoid unit. Thus, the distinction between primary versus secondary WM in granitoid rocks will invariably be subjective and, hence, controversial. In the following discussion we briefly summarize the salient aspects of this study in relation to granitoid petrology, viz., the nature of the WM in the SMB and the implications of its origin in terms of petrogenesis.

Primary Versus Secondary Nature of WM:

Textural and Chemical Evidence

The occurrence of primary WM in felsic igneous rocks is well established from theoretical (Abbott, 1985), experimental (e.g., Huang and Wyllie, 1981; London, 1987; Weidner and Martin, 1987) and natural (i.e., occurrences in volcanic rocks: Pichavant et al., in press; Schleicher and Lippolt, 1981) studies. However, because of inevitable late stage textural modification of granitoid rocks, original grain boundaries of WM are rarely preserved. In addition, the generation of secondary WM is a common subsolidus phenomenon which creates problems in discriminating between the different generations of this phase.

Restricting ourselves soley to textural criteria, there is evidence that primary WM exists in the SMB. This is easier to document in chemically more primitive units than in the relatively volatilerich evolved units. Thus, although textural criteria provide good evidence for the occurrence of some primary WM in the SMB, this reasoning alone does not signify that it constitutes a large percentage of the modal mineralogy.

Chemical analyses of WM have been used by some workers to successfully discriminate textural varleties of WM (e.g., Miller et al., 1981; Anderson and Rowley, 1981; Monier et al., 1984; Monier and Robert, 1986). Application of a variety of discriminant diagrams using major element chemistry for WM of the SMB (e.g., Fig. 3 of Clarke, 1981, and Fig. 2 of Miller et al., 1981) proved inconclusive in distinguishing texturally primary versus secondary grains in this study.

However, a suite of muscovite separates indicates general differences in major element chemistry which broadly correspond to bulk rock composition of the host. This was further illustrated with trace element data which indicated consistent enrichment/depletion trends for a variety of elements (e.g., Rb, Sr, Ba, L1, Cs). The volatile chemistry (1.e., F, L1) of WM in the SMB also shows consistent enrichment towards the more evolved suites and, along with some of the trace elements $(\mathrm{Rb}, \mathrm{Cs})$, reflects crystal-chemical controls (FIg. $6)$. Hence, the use of trace element chemistry appears to provide a means of determining whether the composition of the WM is consistent with the bulk composition of the host rock. For example, the progressive increase of $\mathrm{Rb}, \mathrm{Li}, \mathrm{Cs}$ and $\mathrm{F}$ with a concomitant depletion of $\mathrm{Ba}$ and $\mathrm{Sr}$ in the WM of the SMB is commensurate with the chemical evolution of the host rocks and argues for their primary origin. If the WM formed as a result of local replacement of adjacent minerals (biotite, feldspars, cordierite), the consistent trace element patterns documented herein would not be expected. Instead, we would expect irregular trends as are amply demonstrated by the chemistry of WM from greisen samples in Figures 6 and 7.

The major element composition of WM in a felsic igneous rock is controlled by the physio-chemical conditions of the melt (e.g., Monier and Robert, 1986), although the trace elements are more dependent on crystal-chemical controls. Thus, the vast1y different compositions of WM from the EKL compared to that of the SMB are attributed to both the aforementioned parameters. Obviously, major element chemical criteria establised for primary WM in the SMB are not going to be applicable to the WM in the EKL, and vice versa. Similarly, the trace element (including REE) contents of the WM in the two suites differ markedly. We again emnhasize that WM in the EKL is chemically quite distinct from the WM of clearly secondary origin (i.e.. greisens) at East Kemptville, presumably as a result of varying physio-chemical conditions during mineral growth.

\section{Implications of White Mica on the Petrology} of the South Mountain Batholith

Results of our textural and chemical study of WM in the SMB indicate that some of this mineralogy is of primary magmatic nature. Because it is inferred to occur as a primary phase in even the most primitive unit (i.e., granodiorite), the peraluminous nature of the SMB is an original feature (e.g. , Zen, 1986). In fact, the consistent chemistry of WM within different units of the SMB suggest 1ittle change in bulk chemistry for the samples studied, except for the greisens.

The chemistry of WM in the ternary diagram of Monier and Robert (1986, Fig. 4) indicates different temperatures of equilibration for the micas from a variety of host rocks. Although the temperatures (i.e., $400-600^{\circ} \mathrm{C}$ ) are obviously not magmatic, they indicate the extent of subsolidus, thermal re-equilibration. As would be expected, the fluid-rock interaction in the more evolved phases extended to lower temperatures. The deviation of the East Kemptville WM from the higher temperature isotherms in Figure 4 is related to the fact that the experiments of Monier and Robert (1986) involved biotite-muscovite equilibria. whereas biotite is absent in the EKL.

Since $W M$ is inferred to have been a stable magmatic phase during the evolution of the SMB, appropriate pressure conditions required to stabilize muscovite must have prevailed. As pointed out earlier by Miller et al. (1981) and Anderson and Rowley (1981), the multitude of influencing variables makes pressure estimates difficult. The most important of these factors are the non-ideal chemistry of the WM and the work of Velde (1965, 1967) which indicated a strong temperature-pressure dependence for phengite stability. Previous concerns that octahedral impurities in WM implied low temperature, and hence high pressure of formation, have been contested by Monier and Robert (1986). They showed that a biotitic substitution mechanism can accommodate impurities and thus allow lower pressures of formation. The recent experimental work of Weidner and Martin (1987), on a rock of different bulk 
composition than the SMB but not unlike the EKL, indicates that muscovite can be a stable liquidus phase up to $680^{\circ} \mathrm{C}$ at $1 \mathrm{~kb}$ and $700^{\circ} \mathrm{C}$ at $4 \mathrm{~kb}$. A1though this experimental work was on a F-rich (ca. 1.5 wt.\% F) leucogranite, the presence of $0.2-$ 1.0 wt.\% $F$ in the muscovites of this study indicates that its stability is probably somewhat higher than that inferred for end member $\mathrm{OH}-$ muscovite (Kerrick, 1972; Chatterjee and Johannes, 1974). A stability limit somewhere between these two extremes is probable for the WM in the SMB which would permit emplacement to a leve1 equivalent to ca. $2 \mathrm{~kb}$ pressure (1.e., 6-8 km) based on the phase equilibria established by Weidner and Martin (1987). An estimate of the water content of the melt can also be made by examining the isobaric phase relations established by Huang and Wyllie (1981) for a S-type granite, in combination with the textural observations of WM in the SMB. The late appearance of this phase is consistent with $<2-3$ wt.\% $\mathrm{H}_{2} \mathrm{O}$ in the melt.

\section{CONCLUSIONS}

A textural and chemical study of WM in granitoid rocks of the SMB and EKL indicates that a primary magmatic origin for this phase is probable. While textural criteria alone only suffice to indicate that a small modal percentage of the WM is primary, the chemistry of the mineral provides evidence that a large proportion of the WM formed as an integral part of the magmatic (i.e., crystal-melt equilibria) evolution of the suites studied. The best evidence is provided. by the systematic increase in $F$ and trace element abundances in the WM which mimic trends established for whole rock chemistry by previous studies; hence, this suggests that the WM formed as part of the primary magmatic history of the granitoids. In contrast, WM from grelsens show irregular chemical trends which are attributed to the highly variable chemistry of the protoliths. Use of major element discriminant diagrams (e.g., Miller et al., 1981) to distinguish primary versus secondary WM are not conclusive. This reflects the importance of bulk rock composition, and the radically different compositions of WM from the SMB versus EKI illustrates this point well. This study indicates that the trace and volatile element chemistry of WM is perhaps the most viable and reliable means of distinguishing between different generations of WM in igneous rocks.

\section{ACKNOWLEDGEMENTS}

The funding for the mapping projects from which these samples were collected and analyzed is a joint Canada-Nova Scotia Mineral Development Agreement. The authors gratefully acknowledge M.A. MacDonald, G.A. O'Re111y, A.K. Chatterjee, M.C. Corey, and R.J. Horne at the Nova Scotia Department of Mines and Energy for their assistance and critical discussion. Dr. S. Jackson (Memorial University), Mr. B. McKay (Dalhousie University) and Mr. C. Cole (Technical University of Nova Scotia) are thanked for assistance with obtaining the chemical data presented herein. Critical reviews of an earlier version of the paper were provided by Drs. D.B. Clarke and C. Miller and are gratefully acknowledged.
ABBOTT, R.N., Jr. 1985. Muscovite-bearing granites in the AFM 11quidus projection. Canadian Mineralogist. 23, pp. 553-561. ANDERSON J.L. and ROWLEY, M.C. 1981. Synkinematic intrusion of peraluminous and associated metaluminous granitic magmas. Whipple Mountains. California. Canadian Mineralogist, 19, pp. 83-101.

CHATTERJEE, N.D., and JOHANNES, W.S. 1974. Thermal stab1l1ty and standard thermodynamic properties of synthetic 2M muscovite. Contributions to Mineralogy and Petrology, 48, pp. 89-114.

CLARKE, D.B. 1981. The mineralogy of peraluminous granites: a review. Canadian Mineralogist. 19, pp. 3-17.

CLARKE, D.B., and MUECKE, G.K. 1985. Review of the petrochemistry and orlgin of the South Mountain Batholith and assoclated plutons, Nova Scotia, Canada. In High Heat Production (HHP) Granites, Hydrothermal Circulation and Ore Genesis. Institute of Mining and Metallurgy. London, England. pp. 41-54.

HANSON, G.N. 1980. Rare earth elements in petrogenetic studies of 1gneous systems. Annual Review Earth and Planetary Science, 8, pp. 371-406.

HUANG, W.L. . and WYLLIE, P.J. 1981. Phase relationships of Stype granite with $\mathrm{H}_{2} \mathrm{O}$ to $35 \mathrm{~kb}$ : muscovite granite from Harney Peak, South Dakota. Journal of Geophysical Research, 86, pp. 10515-10529.

KERRICK, D.M. 1972. Experimental determination of muscovite + quartz stability with $\mathrm{PH}_{2} \mathrm{O}<$ Ptotal. American Journal of Sclence, 272. pp. 946-958.

KONTAK, D.J. 1987. Bast Kemptville leucograntite: a possible mid-Carboniferous topaz granite. In Mines and Minerals Branch. Report of Activities 1986. Bdited by J.L. Bates and D.R. MacDonald. Nova Scotia Department of Mines and Energy, Report 87-1, pp. 81-94.

KONTAK, D.J., STRONG, D.F., and KERRICH, R. 1988. Crysta1melt $\pm f l u i d$ phase equilibria versus late-stage fluld-rock interaction in granitold rocks of the South Mountain Bathollth, Nova Scot1a: whole rock geochemistry and oxygen 1sotope evidence. Maritime Sediments and Atlantic Geology, 24. pp. $97-110$

LONDON, D. 1987. Internal differentiation of rare-element pegmatites: effects of boron, phosphoros and fluorine. Geochimica et Cosmochimica Acta, 51, pp. 403-420.

MACDONALD, M.A., and HORNE, R.J. 1988. The geology and geochemistry of the zoned, peraluminous hallfax Pluton, southcentral Nova Scotia. Maritime Sediments and Atlantic Geology. 24. Pp. 33-45.

MILLER, C.F., STODDARD, E.F., BRADFISH, L.J., and DOLLASE, W.A. 1981. Composition of plutonic muscovite: genetic implications. Canadian Mineralog1st, 19, pp. 25-34.

MONIER, G., MERGOIL-DANIEL, J. , and LABERNARELIERE, H. 1984. Generations successives de muscovites et feldspaths potassiques dans les leucogranite du massif de Millevaches (Massif Central Franca1s). Bulletin de Mineralog1e, 107, pp. 55-68.

MONIER, G., and ROBERT, J.L. 1986. Muscovite solld solutions in the system $\mathrm{K}_{2} \mathrm{O}-\mathrm{MgO}-\mathrm{FeO}-\mathrm{Al}_{2} \mathrm{O}_{3}-\mathrm{S}_{1} \mathrm{O}_{2}-\mathrm{H}_{2} \mathrm{O}$ : an experimental study at 2 kbar $\mathrm{P}^{2}$ and comparison with natural L1-free white micas. Mineralogica1 Magazine, 50, pp. 257-266.

MUECKE, G.K. and CLARKE, D.B. 1981 Geochemical evolution of the South Mountain Bathol1th, Nova Scot1a: rare-earth-element evidence. Canadian Mineralogist, 19, pp. 133-145.

PICHIVANT, M. , KONTAK, D.J. . VALENCIA HERRERA, J. , and CLARK, A.H. In press. The Miocene-P1locene Macusant volcantcs, SE Peru: I. Mineralogy and magmatic evolution of a felsic peraluminous magma. Contributions to Mineralogy and Petrology.

SAAVEDRA, J. 1978. Geochemical and petrological characteristics of mineralised granites of the west centre of Spatn. In Metallization Associated with Acid Magmatism. Edited by M. Stemprok, L. Burnol and G. T1schendorf. Geological Survey of Czechoslovak1a, 3, pp. 279-291.

SCHLEICHER, H., and LIPPOLT, H.J. 1981. Magmat1c muscovite in felsic parts of rhyolites from southwest Germany. Contributions to Mineralogy and Petrology, 28, pp. 220-224.

SPEER, J.A. 1984. Micas in Igneous rocks. In Micas. Edited by S.W. Balley. Mineralogical Society of America, Reviews in Mineralogy, 13, pp. 299-356.

STRONG, D.F., and CHATTERJEE, A.K. 1985. Review of some chemical and mineralogical characteristics of granitold rocks hosting Sn, W, U, Mo depostis in Newfoundland and Nova Scot1a. In High Heat Production (HHP) Granites, Hydrothermal Circulation and Ore Genesis. Institute of Mining and Metallurgy, London, England, pp. 489-516.

STRONG, D.F., and LONGERICH, H.P. 1985. The Inductive1y coupled plasma/mass spectrometer (ICP/MS). Geoscience Canada, 12, pp. 72-75.

VELDE, B. 1965. Phengitic micas: synthes1s, stab1lity and natural occurrences. American Journal of Sc1ence, 263, pp. 
886-913.

VELDE, B. 1967. $\mathrm{S1}^{+4}$ content of natural phengites. Contributions to Mineralogy and Petrology. 14. pp. 250-258.

WEIDNER, J.F., and MARTIN, R.F. 1987. Phase equilibrla of a

fluorine-rich leucogranite from the St. Austell pluton.
Cornwall. Geochimica et Cosmochimica Acta, 51, pp. 1591-1597. ZEN, E-AN. 1986. Aluminum enrichment in silicate melts by fractional crystallization: some mineralogic and petrographic constraints. Journal of Petrology, 27, pp. 1095-1117. 